\title{
U-Shaped Theory in Indonesia: Evidence from Sakernas 2010 and 2017
}

\author{
Indah Lukitasari ${ }^{1, *}$, Prita Ismayani ${ }^{2}$ \\ ${ }^{1}$ Faculty of Economics and Business, Universitas Indonesia \\ ${ }^{2}$ Ministry of Women's Empowerment and Child Protection \\ *Corresponding author. Email: tassandut@gmail.com
}

\begin{abstract}
Female Labor Force Participation Rate (LFPR) in Indonesia showed a plateau trend 20 years ago while economic growth was increasing positively. Since then, high Gross Regional Domestic Product (GRDP) (province level) has not been accompanied by high female LFPR although the Gender Development Index (GDI), which shows a gap between men's and women's development, continues to increase. These result show that the relationship between the GRDP per capita and the female labor force participation did not form a U-Shape. The pattern seen in female LFPR tended to decrease along with the increase in GDP per capita in many provinces. The distribution of female LFPR and the economic growth of Indonesian provinces could be seen through GRDP per capita, and in both 2010 and 2017, they had a pattern similar to that of two decades ago. Bali and East Nusa Tenggara (NTT) are the provinces with the highest female LFPR. However, while NTT has the lowest GRDP of all provinces, Bali has attained a level equal to the national average.
\end{abstract}

Keywords: GDI, LFPR, U-Shape Theory, GRDP, Economic Growth

\section{INTRODUCTION}

Labor Force Participation Rate (LFPR) indicates the supply of labor to the production process of goods and services in the economy (ADB, 2012). In addition to being a key to socio-economic development, the supply of female labor is also important for the advancement of women (Lisaniler and Bhatti, 2005). Unfortunately, female LFPR can be called stagnant or has not changed much in the last 20 years (KemenPPPA and BPS, 2018; ADB, 2016) although Indonesia has a strong economy and continues to grow except in 1998 when it declined from its level in 1997 owing to the financial crisis in Asia. This condition is better than that of India, where the female LFPR was 70\% below that of men from 1990 to 2018. But we are slightly behind Brazil and Malaysia where the female LFPR continues to increase with conditions of $20 \%$ and $25 \%$, respectively, under male labor force.

Goal 5.4 in Sustainable Development Goals (SDGs) recognize and appreciate unpaid care and domestic work through public service provision, social protection infrastructure, and policies and increasing shared responsibility in household and family right nationally. This goal indicates gender equality between women and men in domestic work. The low female LFPR has always been connected to unpaid care worker as women spend more time on housework, child bearing, caring for parents, and on other unpaid activities than men do.

From 1990 to 1992, the female LFPR increased considerably and then slowed down until 1998 when it surged again by around $2 \%$. This was allegedly due to the monetary crisis in which the Indonesian economy experienced a small shock and indirectly caused an increase in female participation in the labor market. Indonesian male and female LFPR in 2017 reached $83.76 \%$ and $50.89 \%$, respectively. The female LFPRs ranged between 40 and $70 \%$ in 2010 and 2017, while the LFPR for men were around $80 \%$ higher (2017 compared to 2010). The average male and female LFPR differences in all provinces rangebetween from 31 14$41 \%$. Bali and Papua are provinces with the highest female labor force participation, though it has declined. Another decrease in female LFPR also showed in Bengkulu, DKI Jakarta, Jateng, Kalbar, Sulbar, Maluku. On the other hand Jambi and West Nusa Tenggara (NTB) show an increase in female LFPR. 


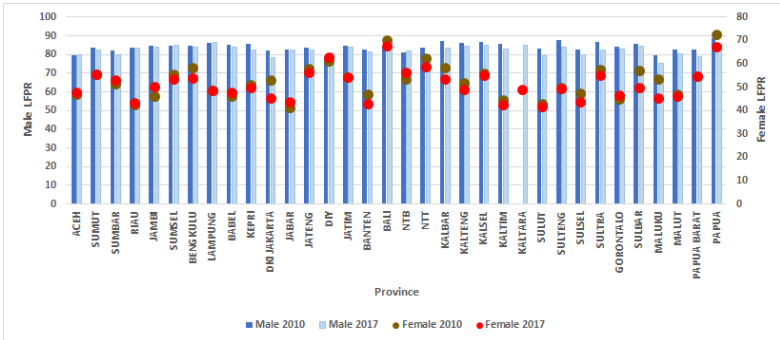

Figure 1 Labor Force Participation Rate by Province and Sex, 2010 and 2017. Source: Keadaan Angkatan Kerja Indonesia, 2010-2017
By way of summary, the female labor force participation in 34 provinces in 2017 has a very huge range in each age group. The largest female labor force group is 2,054,436 women in ranging in age from 35-44 years old. The smallest has only 19,564 women aged $55+$ years. The group of women $35-44$ years old has an average of 364,539 active working women or who are active looking for work.

Table 1. Descriptive Statistics for Female Labor Force Participation, 2017

\begin{tabular}{|l|l|l|l|l|l|}
\hline \multirow{2}{*}{ Labor } & \multicolumn{5}{|l}{ Age Group } \\
\cline { 2 - 6 } & $\mathbf{1 5 - 2 4}$ years old & $\mathbf{2 5 - 3 4}$ years old & $\mathbf{3 5 - 4 4}$ years old & $\mathbf{4 5 - 5 4}$ years old & 55 years old + \\
\hline Mean & $230,272.82$ & $320,436.79$ & $364,538.76$ & $296,075.59$ & $228,409.82$ \\
\hline $\begin{array}{l}\text { Standard } \\
\text { deviation }\end{array}$ & $333,337.75$ & $406,605.40$ & $510,234.28$ & $460,379.38$ & $404,679.27$ \\
\hline Maximum & $1,593,269$ & $1,587,039$ & $2,054,436$ & $1,978,297$ & $1,804,412$ \\
\hline Minimum & 22,935 & 27,840 & 30,031 & 19,564 & 9,325 \\
\hline
\end{tabular}

Source: Keadaan Angkatan Kerja Indonesia, 2017

From 2010 to 2017, the differences in LFPR for Indonesia has been small. In 7 years, the female LFPR has maintained its average at $51.2 \%$, but the standard deviation shows a decline. In 2010 Indonesia had 33 provinces and in 2017, that number fell to 24 since
Kalimantan Utara which separated from Kalimantan Timor legalized in 2012. Similarly, the male LFPR is decreasing from the maximum LFPR but increasing at the minimum rate.

Table 2. Descriptive Statistics for Female Labor Force Participation Rate

\begin{tabular}{|l|l|l|}
\hline Female LFPR & $\mathbf{2 0 1 0}$ & $\mathbf{2 0 1 7}$ \\
\hline mean & 52.81 & 51.21 \\
\hline standard deviation & 7.38 & 6.58 \\
\hline maximum & 72.72 & 67.70 \\
\hline minimum & 41.37 & 41.70 \\
\hline $\mathrm{N}$ & 33 & 34 \\
\hline
\end{tabular}

Source: Labor Force Situation, 2010 and 2017

The GRDP for each province in Indonesia varies greatly. There are seven provinces with very high GRDP above national average, but there are also some provinces with very low levels of GRDP. DKI Jakarta, Kaltim, Kepri, Papua Barat, and Riau were the provinces with the highest GDP per capita in Indonesia in 2010 and 2017. Kaltara, the 34th province of Indonesia, which is a fraction of Kaltim, is also a province with a high GDP per capita. The increase in GDP per capita in Jakarta soared from 2010 to 2017 reaching Rp46,155,610 per year, but was instead accompanied by a decrease in female LFPR of up to $8 \%$ in the period. Similar conditions also occurred in Kaltim, Kepri, and Papua Barat. This is in contrast to what happened to the provinces of Bali, NTB, and NTT where the GDP per capita fell below the national average while the participation of women in the workforce has remained quite high.

In addition to the increase in GDP per capita, GRDP per capita in each province (with respect to Indonesia's 
human development achievements) continues to improve. This is indicated by the increases in all components of the Human Development Index (HDI) including life expectancy, expected years of school, and mean years of school. Meanwhile, the GDI shows that the development gap between men and women is narrowing, where the closer the GDI is to 100 , the smaller the development gap between men and women is (KemenPPPA and BPS, 2018).

Indonesia's HDI in 2017 rose to 68.63 , that is, an increase of 2.3 points from 2010, while the country's GDI in 2010 and 2017 was 89.42 and 90.96, respectively. These HDI data show that Indonesia's human development is at the middle level (UNDP, 2018), and the gender development gap between men and women is decreasing favorably.

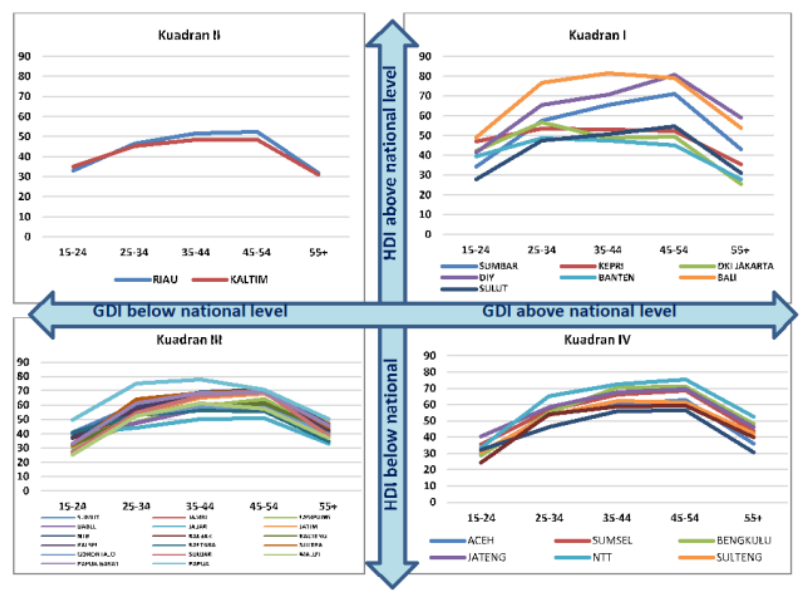

Figure 2 Female Labor Force Participation Rate by Age and Relation between HDI and GDI, 2017. Source: Pembangunan Manusia Berbasis Gender, KemenPPPA dan BPS, 2018, Keadaan Angkatan kerja Indonesia, August 2017.

HDI and GDI achievements are grouped in four () quadrants, with the achievement boundaries above and below the national level. In general, LFPR by age groups will form an inverted U pattern (Pratomo, 2017). Furthermore, if we look at the figure of female LFPR relations according to age groups and the position of HDI and GDI in each province, there are several results, including the following: In quadrant I, there are two groups in the province with HDI and GDI above the national level, namely the higher LFPR group (43-81\%) and the lower LFPR group (27-54\%). These two groups consist of subjects of the age 35-44, 45-54, and 55+. On the one hand, the first awareness group with a higher LFPR is Sumbar, Bali, and DIY. On the other hand, the lower LFPR group is found in Banten, Kepri, Sulut, and DKI Jakarta. This shows that although the human development is high and exceeds the national value, and the development gap between men and women is smaller compared to that of other provinces, the tendency of women to enter the workforce is not high enough. This condition is almost the same as that of the provincial group in quadrant II where the conditions of human development are high, but the development gap between men and women is enlarged indicating that their female LFPR is smaller than that of other provinces.

Provinces in quadrant III have a pattern that is similar to that of quadrants I and II, where the female LFPR rises as the age group rises and decreases when the 55+ age group is the end of the work group to retire. A prominent difference is shown by Papua, where for the young age group (15-24, 25-34, and 35-44), the LFPR is 10 points above that of other provinces in quadrant III.

The description above shows that there is an imbalance in the Indonesian labor force in each province. A region with high per capita gross domestic income does not necessarily stimulate an increase in the female labor force participation. Besides, when seen in terms of its age group, the female LFPR is found to be highest in the 45-54-year age group. The author wishes to see the relationship between the female labor force participation in the economic growth of 34 provinces in Indonesia. Hence the question: Does Indonesia LFPR situation form a U-shaped theory such as presented by Goldin (1995).

\section{LITERATURE REVIEW}

\section{1. $L F P R$}

The LFPR is the percentage of labor force participation compared to the working age population. This labor participation is the sum of the working population and job seekers. The LFPR can be used to measure the extent to which an economy's working age population is actively involved in the economy (Asian Development Bank, 2012). The working age population is the population aged 15 years and above, while the population including the workforce is the population aged 15 years and above and who work, or have a job even if temporarily absent from work and unemployment (Badan Pusat Statistik, 2017).

\subsection{Woman and Labor Force Market}

The neoclassical theory states that the time allocated by women to maximize their utility makes them decide whether or not to participate in the labor market. They do this by considering the value that will be obtained if they spend time in the labor market or outside it. The decision of women to work is the result of a joint decision in the household and the time allocation depends on the characteristics of the household (child, house size, etc.) (Borjas, 2016; Becker, 1965). 
There are segregation job between female and male, each of them has their own sector. The manufacturing sector is dominated by male workers, and clerical jobs are dominated by female workers (Anker, 1998).

\subsection{Gross Regional Domestic Product (GRDP)}

The GRDP is an important indicator for determining the economic conditions in a country within a certain period. The GRDP is obtained by summing the value of the final goods or services produced by all economic units. The GRDP is divided into current prices and constant prices, and at constant prices, the GRDP shows the value added of goods and services calculated by using prevailing prices of one particular year as the base price, while at current prices, the GRDP is calculated by using the current prices every year. This study used GRDP constant prices (Badan Pusat Statistik, 2018).

\subsection{Relation Between Female LFPR and Economic Development (U-Shaped Theory)}

There is a relationship between economic development and the female LFPR in the labor market. In regions that have a very low income level and are dominated by agriculture, there is a large female labor force participation. Women are included in the workforce at times as paid workers and at other times as family unpaid workers. Furthermore, this participation will decline in middle-income regions along with the entry of technology (Goldin, 1995) and the female workers will transition to industrial sectors that are usually dominated by men (Verick, 2014). When the education of women increases and the value of their time in the labor market also increases. Thus, women will once again become the paid labor force (Goldin, 1995) and meet the demand for workers in the service sector (Verick, 2014).

According to one research, the structural transition at the micro-economic level along with the development process, has caused women and children to be affected by macro-economic policies. However, women did not move immediately into the labor market and relied on their husbands to provide the household income (Corner, 1996).

\subsection{Income and Subtitution Effects}

The income and substitution effects will respond to the labor choice of whether to work or to have leisure when income is increasing, and this will affect the female LFPR. On the one hand, when leisure is a normal good, the income effect will be dominant. Thus, women will enjoy their wealth, and this will give rise to a female LFPR decrease. On the other hand, the female LFPR will increase when the substitution effect is dominant (Borjas, 2016).

\section{RESEARCH METHODS}

The sources for the 2010 and 2017 data used in this study, such as the National Labor Survey; the Gross Regional Domestic Prices (constant), were obtained from the Badan Pusat Statistik. The variables used were log GDP per capita and LFPR with a quadratic regression line of log GDP per capita. The method used is descriptive analysis through cross tabulation and graphs.

\section{DISCUSSION}

The U-Shape theory is generally used to configure differences in economic conditions in various countries. But because of the vast territory of Indonesia and the fact that it consists of 34 provinces with many different characteristics, the author would like to see whether the theory applies to Indonesia.

Having focused on developing countries, Verick (2014) has found that although the cross-sectional data of that study did show a U-shaped relationship between female labor force participation and GDP per capita, the relationship was not strong. Besides, it did not reveal a consistent trend at the state level. Meanwhile, the Asian Development Bank (2016) also performed a similar test for some different countries with different levels and produced a form consistent with the U-Shape theory although in more superficial shallow forms.

Al Rakhis (2015) explained that the effect of gender inequality in economic growth is unclear because in the literature, it is mentioned that the relationship between female labor force participation and GDP was highly significant. Yet, this result seems to be different for the Saudi Arabian economy. The main driver of the Saudi Arabian economy is the formation of capital or investment and population growth with the marginal effect of male LFPR. There are different gender inequality effects that also occur in Indonesia.

The patterns shown in 2010 and 2017 were almost the same, where Bali, Papua, NTT and DIY had the highest female LFPR although the percentage declined in 2017 and the GDP per capita increased. Figure III illustrates that the relationship between GRDP per capita and the female labor force participation was not Ushaped; the pattern seen in female LFPR tended to decrease along with the increase in GDP per capita in one province. This pattern was different from the situation in many other countries where gender inequality in employment had a sizeable negative impact on economic growth (Klasen and Lamanna, 2003).

Human capital is capital that a person brings with them upon entering the labor market. It is partly derived from formal education or training (Borjas, 2016). One indicator of education included in the HDI and GDI is 
the mean years of school (MYS). In 2017, the female MYS of 7.56

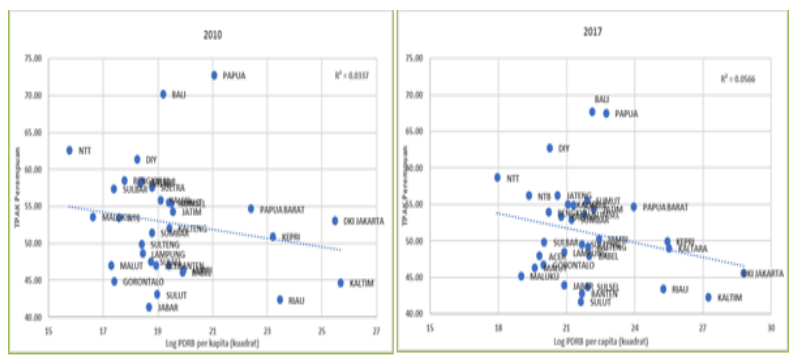

Figure 3 Relation Between Log GRDP Capita and Female LFPR in 34 Provinces. Source: https://www.bps.go.id; Labor Force Situation, 2010 and 2017

Years was lower than the male MYS of 8.56 years. The provinces with the highest female and male MYS were in DKI Jakarta, Kepri. Sulut and Maluku provinces also had high MYS even though the GRDP was below the national average. However, the LFPR was low, at $41.70 \%$ and $44.46 \%$ in 2017. The difference in MYS that averaged less than one year in all provinces in Indonesia shows that human capital offered upon entry into the labor market between women and men was the same, but the facts show that not all women entered the workforce (Lisaniler and Bhatti, 2005).

Investigating the percentage of women who worked during the previous week by province, and the highest education attained revealed that in urban areas, the dominant factors was high school education and above (52.72\%), but in rural areas, there were more people who graduated from elementary school and under employed (60.82\%), (Badan Pusat Statistik, 2017). In total, there were more women with lower primary education $(44.94 \%)$ working in elementary schools. There were also those who graduated from high school (38.52\%) and those from junior high school (16.54\%). In Bali, the population of women who worked was almost the same between those who graduated from high school and above $(43.89 \%)$ and those who graduated from elementary school $(41.62 \%)$. But, for Papua and NTT had the largest proportion of those who graduated from elementary school to below that level. In provinces with high per capita GRDP, the highest education for working women was that of high school and above. This shows that provinces with high GRDP needed well-educated staff and had the capability to create effective human capital.

Educational achievement was apparently not enough to increase female's participation in the workforce. A further view shows the contribution of GRDP according to the field of business, the province with the highest GRDP is dominated by the mining and excavation sector, followed by the processing industry, agriculture, forestry, and excavation construction. Papua Barat is a region with a processing industry production and more specifically processing petroleum products, thus making GRDP per capita one of the highest in Indonesia. All of these business fields are generally dominated by male workers and with a relatively high salaries offered. This can result in a low supply of female labor in the province because their life needs are met by their husbands or other male relatives. According to economic theory, people will decide to work or enjoy leisure, and what they will gain from work must be more valuable than their leisure.

NTT with the lowest GRDP had a high female LFPR in 2010 and 2017. The largest share of GRDP in NTT was agriculture, forestry and the fishing sector (about $31.89 \%$ in 2010 and $27.97 \%$ in 2017). This allows NTT to have a high female LFPR. Slightly more than threequarters $(75.85 \%)$ of female workers in NTT were informal workers and the largest composition was the self-employed assisted by non-permanent/Unpaid Workers and Unpaid workers (Badan Pusat Statistik, 2017).

The average wage received by women who worked as laborers (formal sector) throughout Indonesia was always well below the average wage of workers/male employees. Wage uncertainty was increasingly felt by informal workers. Female informal workers were found in all provinces, even in Bali and Papua, which had the highest female LFPR. Papua had the highest number of female informal workers in Indonesia, above the national level. It shows that high female LFPR was not always a good sign. In fact, female workers worked more in dangerous areas, thus making them vulnerable and do not have a decent work with less protection compare than man than male workers had.

Another factor that was thought to affect working women was their religion and marital status. Alam, Amin and McCormick (2018) explained that Hindu women who were married or single, living in cities or in villages were more likely to work than those of other religions. Putting aside the explanatory factors, Bali, with Hindu as a majority religion, shows the highest female LFPR compared to other provinces.

Women with the highest number of working hours, that is, more than 40 hours per week belonged to the provinces of Kepri, Jakarta, Banten, and East Kalimantan. They were mostly in the trade sector, food, and accommodation services. Jakarta had a low female LFPR. Yet, if women worked, they had many working hours. Women in NTT had the most working hours, from 1-34 hours a week, by virtue of that province having the highest proportion of employment in the agricultural, plantation, forestry, hunting, and fisheries sectors. 


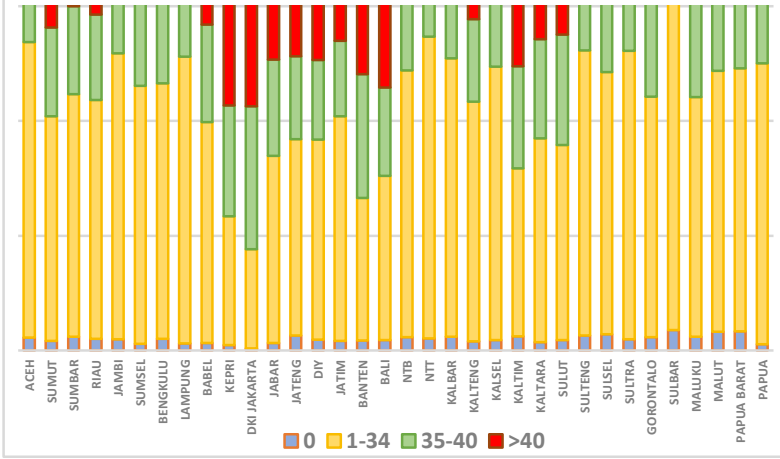

Figure 4 Female Working Hours per Week, 2017. Source: Labor Force Situation, 2010 and 2017

Sulut, Banten, and Jabar always were the provinces with the lowest LFPR. Sulut had the highest Gender Empowerment Measurement (GEM) with a high female representation in parliament but have been unable to bring up their female LFPR. On the other hand, Banten and Jabar were dominated by the manufacturing sector and identify with men's work. This could be the reason that these two provinces had the lowest female LFPR.

In general, provinces with the highest per capita GRDP, the highest share was dominated by the business fields dominated by men. Separation of work by sex is a labor issue that has long emerged in the labor market throughout the country as well as in industrial capitalist countries, former communist countries, and developing countries (Anker, 1998).

The substitution and income effects assumed will affect the female LFPR and the strongest will be varied in each province. The first case is the substitution effect. Female workers will be allotted more work hours when wages increase. On the other hand, the income effect pushes female workers to choose more leisure more rather than more work hours. High GRDP growth provides female workers with the opportunity to earn a higher income, and assuming that the income effect is large in Indonesia, the female LFPR will have a negative relationship. The effect of male wages may also be negative on the female labor force participation if higher wages of male workers suppressed female labor force participation by restricting them to their home (Fatima and Sultana, 2009).

Papua Barat, Kepri, Riau, Kaltim, and DKI Jakarta, which have larger GRDP per capita, would create larger household income that could give a chance to a household member to get higher education and also make women sign out of the labor force (income effect dominant).

\section{CONCLUSION}

In provinces with a high HDI and GDI, thus making two groups of female labor force participation, Sumbar, Bali, and DIY had a high female LFPR, while in Banten, Kepri, Sulut, and DKI Jakarta had a low labor force participation for each age group. Indonesia is a large country with varied characteristics of GRDP that include the main types of business fields that contribute to the GRDP, MYS, and LFPR. DKI Jakarta, Kaltim, Kepri, Papua Barat, Riau, and Kaltara were the provinces with the highest GRDP per capita in Indonesia in 2017, but the provinces of Bali and Papua were the provinces with the largest female LFPR. These result show that the relationship between the GRDP per capita and the female labor force participation did not form a U-Shape. The pattern seen in female LFPR tended to decrease along with the increase in GDP per capita in many provinces. Various economies of provinces of Indonesia reveal different achievements of female LFPR different. Two economies of the same magnitude of GRDP per capita can produce different levels of female LFPR.

NTT had the same pattern as described by Goldin (1995) because it was dominated by its agricultural sector, had low income, and gave way to high female LFPR. But high female LFPR was not always a good sign. Female workers worked more in dangerous areas, which made them vulnerable and do not have a decent work with less protection compare than man than male workers had.

Banten and Jabar were dominated by the manufacturing sector and identified with men's work. That could be the reason that Banten and Jabar had the lowest female LFPR, while Sulut with the highest GEM - and one of the indicators being female representation in parliament-had the highest score in Indonesia although unable to increase their female LFPR.

Larger GRDP per capita would make larger household income that could provide a household member with the chance to get a higher education and also push women sign out of labor force (income effect dominant).

An inverted $U$ pattern for working age women in Indonesia is different from that seen in South Korea. South Korea has a policy in place to reduce discrimination in the labor market. Policies in the form of mitigating gender inequality by reducing working time for women in the household, taking care of children and improving women's education (Kim, 2016).

Many female workers are vulnerable as they work in dangerous areas with less protection than do men. For this reason, there should be affirmative policies focused on female development with respect to their skills and education. Greater female participation is needed in 
parliament so as to empower and protect female workers in the labor market.

The diverse patterns for high or low female LFPRs in each province of Indonesia are interesting for further study by looking at existing theories and empirical studies to determine what factors explain women's decisions to enter the workforce in the 34 provinces of Indonesia. By regression panel method and Concern on the macro conditions that occur in each province which assumed influencing the female LFPR is expected to be carried out in further research.

\section{REFERENCES}

[1] Asian Development Bank. Key Indicators for Asia and The Pacific 2012. 43rd ed. Manila: ADB, 2012.

[2] ADB. Analysis of Trends and Challenges in the Indonesian Labor Market. Manila: ADB, 2016.

[3] ADB. Policy Brief on Female Labor Force Participation in Pakistan. ADB Briefs No. 70 October 2016, 2016.

[4] Alam, I., Amin, S. and McCormick, K. 'The Effect of Religion on Women's Labor Force Participation Rates in Indonesia'. Journal of the Asia Pacific Economy,

23(1), 2018, 31-50, DOI: 10.1080/13547860.2017.1351791 diakses.

[5] Al Rakhis, M. Impact of Gender Inequality on Economic Growth in the Arab Region. Kuwait City: SciencesPo Kuwait Program, 2015.

[6] Anker, R. Gender and Jobs: Sex segregation of occupations in the world. Geneva: International Labour Office, 1998.

[7] Badan Pusat Statistik. Produk Domestik Regional Bruto Provinsi-Provinsi di Indonesia menurut Lapangan Usaha 2013-2017. Jakarta: CV. Josevindo, 2018.

[8] Badan Pusat Statistik. Keadaan Angkatan Kerja di Indonesia. Jakarta: BPS, 2017.

[9] Becker, G. A Theory of The Allocation of Time. The Economic Journal. 75(299), 1965, pp 39-41.

[10] Borjas, G. Labor Economics. 7th ed. Volume 113. pp. United States: Mc Graw Hill Education, 2016.
[11] Corner, L. Women, men and Economics: The Gender-Differentiated Impact of Macroeconomics. New York: United Nations Foundation for the Development of Women, 1996.

[12] Fatima, A. and Sultana, H. Tracing out the UShape Relationship Between Female Labor Force Participation Rate and Economic Development for Pakistan. International Journal of Social Economics 236(1/2). 2009, pp. 182-198.

[13] Goldin, Claudia. The U-Shaped Female Labor Force Function in Economic Development and Economic History. Cambridge: National Bureau of Economic Research, 1995.

[14]KemenPPPA and BPS. Profil Perempuan Indonesia Tahun 2018. Jakarta: Kementerian Pemberdayaan perempuan dan Perlindungan Anak, 2018.

[15] Kim, J. et al. Impact of Gender Inequality on The Republic of Korea's long-Term Economic Growth: An application of the theoretical model of gender inequality and economic growth. ADB Economics Working Paper Series No 473. January 2016. Manila: ADB, 2016.

[16] Klasen, S., and Lamanna, F. The Impact of Gender Inequality in Education and Employment on Economic Growth in the Middle East and North Africa. World Bank Report. New York: World Bank, 2003.

[17] Lisaniler, F. and Bhatti, F. Determinant of Labor Force Participation: A case of Cyprus, 2005, [online] Available at: https://www.researchgate.net/publication/26200534 9 [Accessed 9 May 2019].

[18] Pratomo, D. Pendidikandan partisipasi Angkatan Kerja Wanita di Inonesia: Aanalisis Terhadap Hipotesis Kurva-U. Jurnal Ekonomi Kuantitatif Terapan, 10(2). 2017, pp. 1-8.

[19] UNDP. Human Development Reports. 2018, [online] Available at: http://hdr.undp.org/en/composite/HDI [Accessed 30 Nov. 2018].

[20] Verick, S. Female labor force participation in developing countries. 2014, [online] Available at: https://wol.iza.org/articles/female-labor-forceparticipation-in-developing-countries/long [Accessed: $30 \quad$ Nov. 2018]. 